\title{
Introduction
}

7 wenty-five years ago, Ilan Stavans published Imagining Columbus: The Literary Voyage (1993). Like Columbus in his ambitious goal to chart a new course to India, Stavans, as a scholar, set out to chart his own journey as a literary critic, claiming multiple canons along the way. Indeed, in that year alone, he also published a book on Mexico's detective novels, and an anthology about being Latino/a in the United States. Since then, his output has been enormous. Stavans has authored, co-authored, edited, translated, and written introductions and prefaces to more than one hundred books on a wide variety of subjects ranging from Miguel de Cervantes to Isaac Bashevis Singer, from Jorge Luis Borges to Luis Leal, from Spanglish to graphic novels. He has hosted talk shows and podcasts; his fiction has been adapted for the stage and the big screen; he has written for countless general audience magazines and journals; and he has received many awards such as the Guggenheim Fellowship, Chile's Presidential Medal, the Rubén Darío Medal, the National Jewish Book Award, and the Latino Hall of Fame award. His most recent endeavor, Restless Books, stands to become one of his most important contributions yet with its focus on discovering, publishing, and promoting new immigrant fiction. The man, as one reporter noted, has "energy to burn" and his energy does not appear to be abating. 1

Stavans's wide ranging endeavors, however, have not transpired quietly. For all his contributions, there remains a struggle amongst academic critics, from those who dismiss him as a lightweight to those that consider him influential. How can he be both? His work-indeed his own self-has sparked a series of heated debates on politics, language, and identity, and on the quantity of his output versus its quality. While he can be credited for attempting to legitimize

1 Scott Heller, “'Living in the Hyphen' Between Latin and American," The Chronicle of Higher Education, January 9, 1998. 
Spanglish, it has not been without a fight from purists. He is responsible for shaping a certain view of Latino/a Studies but not without the complaint that he is not "one of us." ${ }^{2} \mathrm{He}$ has carefully tended to the forgotten voices of Jewish Latin America, but not without questions as to his authority in the field. And he has emerged as a lion anthologizer, rankling those with strong opinions about who should be in and who should be out of different canons. Perhaps the reason that he is welcomed to, or banished from, different literary and cultural fields is because he unabashedly lays claim to them all.

The struggle to interpret his work, and whether his contributions deserve the attention that they garner, will most likely never be resolved. Much of this tension was captured in a November 1999 New York Times article reported by Lynda Richardson, and there is no need to rehash the debate here. ${ }^{3}$ But one thing is certain: Stavans never feels constrained or burdened by critiques directed at him, and thus he will keep insulting the sensibilities of some and dazzling those of others. While this collection is celebratory in nature, it is not naively so; all the contributors are well aware of the good, the bad, and the ugly regarding Stavans's output and the vast terrain he covers, sometimes superficially so. Yet Stavans's work has personally or intellectually impacted each contributor, and here they write about the importance of his work in their lives, careers, and intellectual endeavors. For Luis Loya, it is personal. Stavans's defense of DREAMers and their right to become citizens of American democratic institutions resonates with Loya's experience as a DREAMer. For William Childers, it is the unique manner in which Stavans contextualizes Cervantes's Don Quixote within Latino Studies. For Devin Naar, it is a reflection on a fading language, Ladino, and the work being done to secure its future. For others, like Ruth Behar, Stavans's friendship, intellect, and Jewish Mexican heritage inspires her creativity.

\section{THE BACKGROUND}

Ilan Stavans was born in Mexico City in 1961 to a Jewish family from Poland and Russia. As a child he spoke Yiddish and Spanish, later Hebrew, and then English. His high school years were at a Yiddish shul, the Colegio Israelita, and he later went on to the Universidad Autónoma de México where he wrote two manuscripts,

2 Tey Diana Rebolledo quoted in Lynda Richardson, "How to be Both an Outsider and an Insider; 'The Czar of Latino Literature and Culture' Finds Himself Under Attack," The New York Times, November 13, 1999. 
xii | Introduction

now long forgotten, for his tesis de licenciatura. One was on Franz Rozensweig, and the other was on Bahya ibn Paquda - this range already reflected the eclectic interests that would continue to inspire him throughout his career. After graduating, he served for a short while as a newspaper correspondent for La jornada writing on political and cultural issues, diplomatic meetings, new movie releases, art exhibitions, all while under the pseudonym of Zuri Balkoff. He also wrote for a newspaper called Excélsior using his own name, whose ideology was in stark contrast to La jornada. Playing at the edges of ideological positions, his last piece for La jornada, a critical look at Andy Warhol, was never published. The editor wanted a laudatory piece; Stavans refused. Soon after, he traveled throughout Europe, Israel, and Latin America. He landed in New York in 1985 and enrolled in the Jewish Theological Seminary for his M.A. and then his Ph.D. at Columbia University, writing his dissertation on the Mexican detective novel. Stavans is currently the Lewis-Sebring Professor in Latin American and Latino Culture at Amherst College, where he has been teaching since 1993.

Stavans's memoir, On Borrowed Words: A Memoir of Language (2002), is constructed on a familiar trope, that of the outsider. His narrative arc follows the archetypal journey of the individual seeking a homeland where their multiple selves will be actualized. It is a familiar narrative to Jews and Latinos alike, the neither here nor there, the both here and there, the outsider fated to always be looking in. He begins his memoir by sharing how he never felt at home in Mexico. Neither the Jewish community nor Mexico allows him to fully embody either identity. As a Jew he is never quite a Mexican, as a Mexican, he can never be fully Jewish. In other words, for Stavans, it is impossible to remain in Mexico and be either a real Mexican or a real Jew or a Mexican Jew. Thus he wanders, through Israel, Europe, Latin America, before finally landing in New York City. There, he dreams of fulfillment, not only because it is the mecca for Jewish public intellectuals, a pantheon that Stavans hopes to join, but also because of the idea that anyone can belong in New York City, that any immigrant can find a home in that metropolis. In New York, though, he also discovers that his Mexican self is what defines him, not his Jewish self; his Jewish identity becomes a non-issue, while his Mexican Latino identity more relevant. And so on.

At heart, then, Stavans's work is tangled up with these sides of his cultural heritage, never fully able to be all of them at once, having society pick and choose how to view him, and forcing him to ascribe to a situational identity. It is the messiness of these varying origins that has served as a compass for his 
intellectual endeavors. He has deftly parlayed his background into a field of study, moving quickly over the different territories: Jewish, Hispanic, Latino, Latin American, American, Mexican, Ashkenazi. As Matthew Glassman and Stacy Klein note in chapter twenty of this volume, Stavans's cultural and ethnic heritage are responsible for defining his modus operandi: "Whether it's completely conscious or not, Ilan likes to push against boundaries and borders, to travel across them and to disturb them." Klein adds, "I think it leads him to curiously weave versus going in a straight line. He tries everything he can to satisfy that hunger."

\section{THE CHAPTERS}

The first four essays in this volume are connected in that they celebrate one of the core themes of Stavans's scholarly work: his versatility. Words like "unorthodox," "incongruous," "changeable," and "impertinent" are used to describe his method and approach to different literary fields. Beth Kissileff, for example, in her essay "Ilan Stavans: Our Meturgeman Par Excellence," likens Stavans to a modern day meturgeman, the religious officiant who translated Hebrew into the vernacular during services. The meturgeman was not only a translator, but also an interpreter, someone who expanded upon the text by adding contemporary details, morals, or historical elements, and transforming the service to something palpable and relevant for the congregants. Stavans, in Kissileff's opinion, embodies this role in his work, drawing from traditional or canonical works and languages, and mixing them up to provide new insights and ruptures in static traditions.

Isabel Durán's essay, "Ilan Stavans, the Life (long) Writer, analyzes Stavans's memoirs, On Borrowed Words: A Memoir of Language (2002), and Return to Centro Histórico: A Mexican Jew Looks for His Roots (2012). Whereas Kissileff sees Stavans as a meturgeman, a translator of culture and language, Durán views him through the lens of the quintessential "brown" scholar (Durán is inspired by Richard Rodriguez's use of the term), by which she means a scholar who is "impertinent" and not wed to a traditional point of reference in literary canons. She sees him as a scholar who respects no boundaries, who disturbs canons and orthodoxies, who pushes against purity. For Durán, the root of this impetus is the personal. Stavans, as she explains, searched for wholeness, and a strong sense of being in each of his identities, Mexican and Jewish, only to be hampered at every turn by society, by perceptions, by 
cultural stereotypes. In the end, Stavans embraces his liminal identity, that of a self-described half and half who exists in no man's land.

Irina Troconis highlights the far-ranging Stavans in her essay "El Iluminado: Ilan Stavans and the Incongruity of the Anti-hero," which begins with a Borges story, "El idioma analítico de John Wilkins." She describes the "feel" of Stavans's El Iluminado, a graphic novel about crypto-Judaism, as akin to the incongruity found in Borges's story that offers the reader an elaborate and absurd ordering of the universe. Stavans's graphic novel-which focuses on the crypto-Jews of the southwest-shares this Borgian quality in its attempt to "present the reader with a multilayered space where incongruity-understood as that which is out of place, inappropriate, inconsonant, and inharmonious - is allowed to flourish." Her analysis, rich and precise, highlights the themes of the previous two essays, Stavans's linguistic and cultural "wall-razing."

Angelina Muñiz-Huberman's essay “Life, Death, and Apotheosis of Words: Dic.tion.ar.y Days," accentuates Stavans's irreverence in Dic.tion.ar.y Days (2005). If a dictionary could pick its author, she states, it would pick Stavans because he understands the true nature of the dictionary as "intimate, erotic, and even eschatological and pornographic.” A dictionary, Muñiz-Huberman states, is an example of a vital and living poetic, something that Stavans ascribes to and accomplishes in these essays about his literary escapades as a "dictionary hunter."

The next three essays focus on Stavans's Quixote: The Novel and the World (2015). Diana de Armas Wilson's essay, “Cave Paintings: Cervantes, Turbans and Heresy," offers an answer to a question that Stavans asks readers in his Quixote: “To what extent is it accurate to visualize Cervantes through a Caucasian prism?" The answer is "not accurate." De Armas Wilson shares Stavans's belief in Cervantes's familiarity with “deviant behavior," his non-conforming, heretical character, his moro-judeo interests. Her essay turns on three issues in response to Stavans's remarks: Cervantes's “intense interest in things Muslim;" his plots to escape captivity in Inquisitorial Spain; and the uses of heresy in his most famous cave painting.

According to Ivan Jaksić, Stavans has been at the forefront of the intellectual movement that has brought fresh dimensions to the concept of Hispanidad to the United States. "Freedom to Pursue the Impossible Dream: Ilan Stavans and Don Quixote" centers on this very idea, as Jaksić examines how Stavans's polemical approach to Don Quixote benefits one of the most canonical literary works of all time. Because Stavans "works from the margins" inward and then, upon reaching the core of the text, pivots away again, his quest, like Don 
Quixote's, has no end. In fact, Stavans's Quixote continues to turn upon itself and, in the process, contributes new ideas about modernity and Hispanidad, humor, angst, and language.

William Childers, meanwhile, in "Stavans Does Quixote," begins with a prologue acknowledging the critiques oftentimes used for Stavans: "interloper," "arriviste," "usurper." Childers, however, instead of criticizing Stavans as a "faux" Cervantes scholar (although he gives us plenty of solid reasons to choose this critical judgement), chooses to focus on Stavans's larger, and perhaps more valuable, enterprise: his situating of "the Spanish classic par excellence in relation to U.S. Latino studies." He unpacks the charge directed toward Stavans, that of Eurocentrism, by arguing that the "yoking" of Don Quixote to the field of Latino Studies is both meaningful and urgent, especially in the current political climate. To not view this text as part of a more expansive Latino/a canon is to somehow participate in a Trumpism, the "demonization" of Latino/as in the United States.

Steven Kellman begins the section on language, Spanglish, and translation by asking "To what extent does the language in which Stavans chooses to write determine the kind of writing he does?" In "Ilan Stavans, Tongue Snatcher, he explores the beloved "hero" of so many of Stavans's books: language itself. Kellman analyzes the extent to which Stavans's quadrilingualism-Spanish, English, Yiddish, Hebrew-determines the kind of writing in which he engages and, by extension, why his advocacy of Spanglish is a natural outcome. Why is his memoir in English? His fiction in Spanish? Does Stavans assign a different function (and literary self) to each of his languages? Finally, Kellman highlights the symmetry in Stavans's multilingualism, one where the imperial languages spoken by the colonial powers are bookended by the unconventional and raffish languages (Yiddish and Spanglish) that contain an underdog sensibility. In the end, Kellman says, if mind (and I would include thought and identity) is language, then "Stavans's mind strains against the constrictions of any single language. $\mathrm{He}$ is a collector and connoisseur of dictionaries who refused to accept any dictionary as prescriptive, an aficionado of linguistic miscegenation in Yiddish and Spanglish, and a professor who scorns academicism."

Sylvia Betti's essay, "El español y el spanglish en la era de Trump," is the only essay of the volume in Spanish. Betti argues that Spanglish should be considered a symbol of the endurance of immigrants in the United States rather than the downfall of the Spanish language. New immigrants to Latino communities continually replenish Spanish and continually mix with both Spanglish and English. Spanglish, what Betti says is sometimes considered 
xvi $\mid$ Introduction

an abomination, a bastard or aberrant language, is not a corrupting influence but an invigorating one and a vital linguistic organ for immigrants.

“'A World Defined by Immigration:' Ambivalence, Translationality, and Mestizaje in Ilan Stavans," by Ivonne García, connects Stavans's work as a cultural and linguistic translator to José Martís journalism during his time writing for the New York Sun. García charts the progression of some of Stavans's favored themes from On Borrowed Words (2001) to Spanglish: The Making of a New American Language (2003) and The United States of Mestizo (2013). She notes Stavans's movement "from exploring the ambiguities and challenges of a diasporic identity, and its imbricated relationship to language, to the self-assured assertion of mestizaje as the present_and impending future — of the United States." García's choice of descriptors in her title reflect the necessary mechanical and existential tools for understanding Latino/a studies and Latino/as in the United States.

Regina Galasso, in her essay "Translation as a Way to Write the City," considers Stavans attraction to the Spanish writer, Felipe Alfau. Alfau, like Stavans, arrived in Manhattan as a young adult, and the bridge between the two men and their linguistic possibilities is emphasized in Alfred Kazin's A Walker in the City. Galasso highlights the similarities between Stavans and Alfau and their choice to write primarily in English, and believes that Stavans recognizes in Alfau a kindred spirit, one who found a borderless space in New York City that allowed for reinvention, for tongue snatching (referring back to Kellman's essay), and for self-switching. "Translation," Galasso writes, "is not only about winning and losing, but it is also about becoming." And in Manhattan, Stavans and Alfau become in English, their non-maternal language.

Stavans's work as a translator is the focus of Christopher Schafenacker's essay, "Returning Borrowed Words: Translation and I can't tell if there is one or not Ilan Stavans's Contribution to the English Language," which discusses how Stavans breaks the golden rule of translation: the "mother tongue" principle. A translator, this rule stipulates, should translate into his own mother tongue. Stavans, of course, breaks this rule, especially with his "transgressive translation ethos” in parts of Don Quixote. Schafenacker views Stavans's translations - of Rulfo, or of Neruda, for example-as intentionally irreverent. "His translations," Schafenacker concludes, "demonstrate that English can accommodate non-normative perspectives and be all the richer in so doing."

Devin Naar's essay, "On Words Reclaimed and the Fate of Ladino," ends the section on language with his personal reflection on Ladino, "the often forgotten Sephardic step-sibling of Yiddish.” Naar's point of departure is Stavans's On 
Borrowed Words, which he uses as a frame to interrogate borrowed words and adopted homelands. He explores the history of his own borrowed words and questions whether or not Ladino is "his" language. Or rather, is it a language that he can reclaim as "his" if the relationship was a tenuous one. He begins with the history of Ladino and Sephardic literature in the Ottoman Empire, braiding the linguistic and cultural with his own family history. Naar mourns the decline of spoken Ladino. But rather than remain passive in the face of its disappearance, he has become a force in maintaining a vibrant program of Sephardic Studies at his home institution, University of Washington. In large part because of his efforts, the program now contains one of the most comprehensive Ladino libraries in the country. In the end, Naar is hopeful that a "new digital afterlife" will create a fresh explosion of Sefaradizm.

The next three essays focus on Stavans as the anthologizer or conversationalist-in-chief. Stephen Sadow, in "Introductions: Ilan Stavans and the 'Jewish Latin America' Series," surveys how Stavans used his introductions to the Jewish Latin America series, published by University of New Mexico press, to reclaim that literature from neglect, to stimulate interest in it as a field of study, and to highlight common themes of that body of work. The University of New Mexico series included nineteen volumes, novels, novellas, short stories, memoirs, essays, folktales, and works of history, a comprehensive service to the writers and their works from 1997-2005. Stavans, as Sadow states, because of his position as series editor, became the de facto molder, promoter, and propagator of a Latin American Jewish canon (a canon creator here, instead of a canon breaker) by bringing to English audiences texts such as Alberto Gerchunoff's Jewish Gauchos of the Pampas or Isaac Goldemberg's The Fragmented Life of Don Jacobo Lerner. While functioning as promoter-in-chief of these texts, Stavans also became a melamed, a teacher, who introduced this world to readers.

Thomas Nulley-Valdés, in turn, surveys Stavans's contribution to latinidad in his essay "Ilan Stavans's Anthologization of the Latino Community in the United States." Through an examination of Growing up Latino: Memoirs and Stories (1993), The Norton Anthology of Latino Literature (2010), and Stavans's commentary on Se habla español: voces Latinas en USA (2000), Nulley-Valdés explores how Stavans's anthologies offer a particular vision of Latino/a identity and community, one that remains deeply connected to its Latin American roots while also shape-shifting to the cultural and political particularities in the United States. Nulley-Valdés asks us to consider Stavans within the framework of "Latinization from above or Latinization from below." Is Stavans vision or 
xviii | Introduction

incursion into latinidad imposed from above or is it a fashioning that begins from below?

In "A Game of Mirrors: The Conversations of Ilan Stavans," Derek Xavier García argues that Stavans's use of conversation is similar to the function of a mirror; the conversations reflect back on Stavans compelling him to meditate upon his place as an academic and a public intellectual. Analyzing the art of conversation as a tool and as a methodological exercise allows Stavans to transpose himself unto others and into other territory, and to cross into topics that interest him. "If," as García writes, "words shape the image of the author in the mind of the reader, then an analysis of Stavans's conversational pieces reveals the subjects and ideas that he holds dear."

Stavans's role as an intellectual and personal mentor serves as the theme for the next two essays. Luis Loya focuses on Stavans's 2011 essay, "Academic Purgatory," a ludic portrait of an undocumented immigrant named Jorge Arbusto (an alias that also translates to George Bush), and his struggle to find opportunities after attaining his doctorate. Arbusto's story is Loya's story, they are one and the same. But it still haunts Loya not only because Stavans writes about Loya who, in turn, writes about himself here, but because it represented the "communal distress, fortitude, and pride" of undocumented immigrants. Loya decided to create a fake interview with himself as Arbusto and much of Loya-Arbusto's reflections about Stavans are part of the essay. In addition, Loya uses his alter ego to suggest an innovative framework to describe the space within which undocumented immigrants live, the Mojarra syndrome. Loya/Arbusto, in his dissertation, used the term "to identify a person who crossed the U.S. border as a mojada/o, swimming or forging a river, navigating the ocean and/or negotiating any other above- or under- ground surface." The mojarra, a type of sea brine, causes an individual to feel that their survival depends on their ability to evade capture. Stavans, as one might expect, does not see this condition, the feeling of being hunted, as a barrier; rather, it is a vehicle for undocumented migrants to achieve their potential. And Loya agrees. The undocumented immigrant, whether in academic institutions or working in the fields, can and must be inventive, and can and must live beyond borders, time, and space.

Carlos Flores's "Mexican Bandit or the Last Intellectual?: Ilan Stavans's Notorious Raid on the Chicano Literary Canon," is a personal and academic reflection about his encounter with Stavans's The Riddle of Cantinflas: Essays on Hispanic Popular Culture in 1999. Flores recounts how his discovery of the essays contributed to his own development as a Chicano writer (he published Sex as a Political Condition: A Border Novel in 2015), and his own Chicano nationalism. 
Stavans's essays were the catalyst that allowed Flores space to question what he perceived as a rigid Chicano/a canon and canon-makers, one that refused to question Sandra Cisneros as the grand dame of the canon, which, in turn, allowed him to write an irreverent and satirical border novel. Flores also nimbly addresses the critiques lobbed at Stavans as an interloper, specifically by asking if Stavans deserves his notoriety. In the end, Flores answers the question his title asks by declaring Stavans a bandido in the best sense of the word: "In stealing our often narrowly nationalistic and uncritical view of ourselves as Chicanos, Stavans qualifies as a bandido. A Mexican bandit. But isn't that what brave intellectuals are supposed to do? Knock down barriers? Throw the gates open? Transgress borders?"

The next section of the volume is a mix. It begins with Ian Campbell's interview with Stavans. The interview summarizes many of the themes included here-translation, multilingualism, Don Quixote, Borges, Stavans's borderless interests, and what Stavans calls his "Talmudic" mind. In chatting about a recent trip to China, Stavans describes the condition of the modern traveler as someone who always lands in places without ever arriving in full. When Campbell asks Stavans how his views on translation have changed over the years, Stavans replies that his views have not changed so much as he himself has. "I have become less stressed, more comfortable within and across languages, and also more relaxed with myself. I know that every translation is a draft and that I must strive for what I see as a perfect imperfection."

Following the interview is a conversation between Matthew Glassman and Stacy Klein, from Double Edge Theatre, who reflect on their collaborations with Stavans. Glassman and Klein describe Stavans as a man who is restless and never satisfied, qualities that lead to collaborations that push the boundaries of orthodoxies, including the classical Renaissance figures such as Cervantes. With Stavans, Don Quixote, for example, becomes "more ecstatic ramshackle, revolutionary, and more Latino, more Hassid and more mardi gras than the classical or Hispanic."

Finally, the volume ends with two poems dedicated to Stavans, one by Ruth Behar and the other by Isaac Goldemberg. Behar writes about her trip with Stavans to Cuba, a trip that included visits to Jewish cemeteries and synagogues, walks along the Malecón, a visit to the tiny black Madonna in Regla, and their meeting with a bookmaker and poet. In commemoration of their trip she dedicates a poem to him, "Broken Streets Of My City," filled with nostalgia for the Jewish Havana of her childhood. Goldemberg, in his poem "Spaces of the Body," uses the sacred space of the synagogue to comment on mortality: "What have we been thinking about?" the poet asks. "The grave, I hope not." 


\section{CONCLUSION}

In the end, these essays demonstrate how Stavans has influenced different fields of study. He has worked to de-ghettoize Latino/a studies by identifying shared themes, he has complicated our thinking about Spanglish, and he has expanded our understanding of Jewish Latin America. The deep variety and richness of the contributions collected are testament to Stavans's own variety and richness of thought. Quite simply, he is not a bureaucrat of ideas or thinking. He is an agenda maker, someone who rewrites the rules and revises the scripts, he is self-willed and full of opinions. And we have responded to his agenda-making.

My late friend and colleague Mark Shechner, who was to have contributed to this volume, considered Stavans to be haunting the grounds of the New York Intellectuals of yesteryear, the Lionel Trillings, the Edmund Wilsons, the Leslie Fiedlers. In closing, as both a tribute to Stavans and to Shechner, I include Shechner's abstract because it highlights the difference between the academic scholar and the public intellectual and helps explain the tension or struggle amongst critics that I refer to earlier in this introduction.

"Ilan Stavans: Nueva York Intelectual"

Every generation in America has had its intellectual trajectory directed by one or two major figures who set the agendas and sparked the debates. In the 1920s, it might have been T.S. Eliot or D.H. Lawrence. In the 1930s and 1940s, Edmund Wilson was such a figure, and others, loosely thought of as the New York Intellectuals, took their cues from him. In the late 1940s and the succeeding decade, that figure became Lionel Trilling. Maybe Saul Bellow as well. After Trilling and Bellow, there was a long dying fall, which the literary academy sought to arrest by turning to the French: Derrida, Lacan, de Man, Foucault, etc. It was an awkward moment in American intellectual life that we are finally past. For a feminist age, Cynthia Ozick and Susan Sontag-temperamentally the Hebraist and the Hellenist respectively-became the bellwethers. The argument can be made that Ilan Stavans is a defining figure for our moment. He represents the intellectual wing of the Hispanic migration and has moved to the center of public discourse, writing about Hebrew, Sephardic poetry, and the "Hispanic Condition" while refusing to cloak himself in its academic costumes. And like all New York intellectuals, he can be pugnacious. 
I propose to build a profile of the New York Intellectual, focusing on independence: an adversarial stance toward group think and academic fashion. (For early generations it was an opposition to formulaic Leftism, to what Lionel Trilling called the "Liberal Imagination.") For Stavans, the "Liberal Imagination" has morphed into the pieties of the Latino/Latina literary academy and its fashionable postures of "subversiveness" and "empowerment." As a group, public intellectuals are asystematic and eclectic, unbounded by curriculum or discipline. Their "sixth sense" is history, not theory. Their métier is more informed opinion than sustained scholarship. They prefer independent judgment to system. The New York Intellectual tends to be bilingual or even multilingual, and the tension between languages provides him/her/them with a stereoscopic perspective on ideas and ideologies, even on themselves. Edmund Wilson, the Yankee, was fluent in French and taught himself Russian and Hebrew; Philip Rahv was Russian-born; Hannah Arendt German-born; the Frankfurt School were German-English bilingual; Irving Howe, Saul Bellow, Daniel Bell, Isaac Rosenfeld, and Cynthia Ozick grew up speaking Yiddish, and some of them also knew Hebrew; Susan Sontag was fluent in French. For Stavans, the informing languages are Spanish and Hebrew. As writers, they favor clarity over opacity, the vernacular over crit-speak, public discourse over private languages. Ilan Stavans has designed his career with such a model in mind, and with Edmund Wilson, Lionel Trilling, and Walter Benjamin as his rabbis. 
